\title{
Antioxidant nutrition in Atlantic salmon (Salmo salar) parr and post-smolt, fed diets with high inclusion of plant ingredients and graded levels of micronutrients and selected amino acids
}

Kristin Hamre $^{\text {Corresp., }}{ }^{1,2}{ }^{\text {， Nini H. Sissener }}{ }^{1}{ }^{\text {， Erik-Jan Lock }}{ }^{1}{ }^{\text {， Pål A. Olsvik }}{ }^{1}$ ， Marit Espe ${ }^{1}$, Bente E. Torstensen 1, Joana Silva ${ }^{3}$, Johan Johansen ${ }^{4}$, Rune Waagbø ${ }^{1,2}$, Gro-Ingunn Hemre

${ }^{1}$ National Institute of Nutrition and Seafood Research (NIFES), Bergen, Norway

2 Department of Biology, University of Bergen, Bergen, Norway

3 Biomar AS, Trondheim, Norway

${ }^{4}$ GIFAS, Inndyr, Norway

Corresponding Author: Kristin Hamre

Email address: kha@nifes.no

The shift from marine to plant based ingredients in fish feeds affects the dietary concentrations and bioavailability of micronutrients, amino acids and lipids and consequently warrants a re-evaluation of dietary nutrient recommendations. In the present study, an Atlantic salmon diet high in plant ingredients was supplemented with graded levels of nutrient premix (NP), containing selected amino acids, taurine, cholesterol, vitamins and minerals. This article presents the results on the antioxidant nutrients vitamin C, E and selenium (Se), and effects on tissue redox status. The feed ingredients appeared to contain sufficient levels of vitamin $\mathrm{E}$ and Se to cover the requirements to prevent clinical deficiency symptoms. The body levels of $\alpha$-tocopherol (TOH) in parr and that of Se in parr and post-smolt showed a linear relationship with dietary concentration, while $\alpha-\mathrm{TOH}$ in post-smolt seemed to be saturable with a breakpoint near $140 \mathrm{mg} \mathrm{kg}^{-1}$. Ascorbic acid (Asc) concentration in the basal feed was below the expected minimum requirement, but the experimental period was probably too short for the fish to develop visible deficiency symptoms. Asc was saturable in both parr and post-smolt whole body at dietary concentrations of 190 and $63-89 \mathrm{mg} \mathrm{kg}^{-1}$, respectively. Maximum whole body Asc concentration was approximately $40 \mathrm{mg} \mathrm{kg}^{-1}$ in parr and $14 \mathrm{mg} \mathrm{kg}^{-1}$ in post-smolt. Retention ranged from 41 to $10 \%$ in parr and from -206 to $12 \%$ in post-smolt with increasing NP supplementation. This indicates that the post-smolts had an extraordinarily high consumption of Asc. Analyses of glutathione (GSH) and glutathione disulphide (GSSG) concentrations and the calculated GSH based redox potentials in liver and muscle tissue, indicated only minor effects of diets on redox regulation. However, the post-smolt were more oxidized than the parr. This was supported by the high consumption of Asc and high expression of gpx1 and gpx3 in liver. Based on the present trials, the recommendations for 
supplementation of vitamin $\mathrm{C}$ and $\mathrm{E}$ in diets for Atlantic salmon are similar to current practices, e.g 150-200 mg kg-1 of $\alpha-\mathrm{TOH}$ and $190 \mathrm{mg} \mathrm{kg}^{-1}$ Asc which was the saturating concentration in parr. Higher concentrations than what would prevent clinical deficiency symptoms are necessary to protect fish against incidents of oxidative stress and to improve immune and stress responses. There were no indications that the Se requirement exceeded the current recommendation of $0.3 \mathrm{mg} \mathrm{kg}^{-1}$. 
1 Antioxidant nutrition in Atlantic salmon ([i]Salmo salar[i]) parr and post-smolt, fed diets with high

2 inclusion of plant ingredients and graded levels of micronutrients and selected amino acids

3

4 K. Hamre ${ }^{1,4}$, N.H. Sissener ${ }^{1}$, E.J. Lock ${ }^{1}$, P.A. Olsvik ${ }^{1}$, M. Espe ${ }^{1}$, B.E. Torstensen ${ }^{1}$, J. Silva ${ }^{2}$, J. Johansen ${ }^{3}$, R.

5 Waagb $\emptyset^{1,4}$, G.-I. Hemre ${ }^{1}$.

6

$7 \quad{ }^{1}$ National Institute of Seafood and Nutrition Research (NIFES), Bergen, Norway

$8 \quad{ }^{2}$ Biomar AS, Trondheim, Norway

$9 \quad{ }^{3}$ GIFAS, Inndyr, Norway

$10{ }^{4}$ University of Bergen, Norway

13 Corresponding author:

14 K. Hamre

15 NIFES, Postboks 2029 Nordnes

5817 Bergen, Norway

17 e-mail: kha@nifes.no

phone: (+47) 48185034 


\section{Abstract}

The shift from marine to plant based ingredients in fish feeds affects the dietary concentrations and bioavailability of micronutrients, amino acids and lipids and consequently warrants a re-evaluation of dietary nutrient recommendations. In the present study, an Atlantic salmon diet high in plant ingredients was supplemented with graded levels of nutrient premix (NP), containing selected amino acids, taurine, cholesterol, vitamins and minerals. This article presents the results on the antioxidant nutrients vitamin C, E and selenium (Se), and effects on tissue redox status. The feed ingredients appeared to contain sufficient levels of vitamin E and Se to cover the requirements to prevent clinical deficiency symptoms. The body levels of $\alpha$-tocopherol (TOH) in parr and that of Se in parr and postsmolt showed a linear relationship with dietary concentration, while $\alpha-\mathrm{TOH}$ in post-smolt seemed to be saturable with a breakpoint near $140 \mathrm{mg} \mathrm{kg}^{-1}$. Ascorbic acid (Asc) concentration in the basal feed was below the expected minimum requirement, but the experimental period was probably too short for the fish to develop visible deficiency symptoms. Asc was saturable in both parr and post-smolt whole body at dietary concentrations of 190 and $63-89 \mathrm{mg} \mathrm{kg}$, respectively. Maximum whole body Asc concentration was approximately $40 \mathrm{mg} \mathrm{kg}^{-1}$ in parr and $14 \mathrm{mg} \mathrm{kg}^{-1}$ in post-smolt. Retention ranged from 41 to $10 \%$ in parr and from -206 to $12 \%$ in post-smolt with increasing NP supplementation. This indicates that the post-smolts had an extraordinarily high consumption of Asc. Analyses of glutathione (GSH) and glutathione disulphide (GSSG) concentrations and the calculated GSH based redox potentials in liver and muscle tissue, indicated only minor effects of diets on redox regulation. However, the post-smolt were more oxidized than the parr. This was supported by the high consumption of Asc and high expression of gpx1 and gpx3 in liver. Based on the present trials, the recommendations for supplementation of vitamin $\mathrm{C}$ and $\mathrm{E}$ in diets for Atlantic salmon are similar to current practices, e.g $150-200 \mathrm{mg} \mathrm{kg}^{-1}$ of $\alpha-\mathrm{TOH}$ and $190 \mathrm{mg} \mathrm{kg}^{-1}$ Asc which was the saturating concentration in parr. Higher concentrations than what would prevent clinical deficiency symptoms are necessary to protect fish against incidents of oxidative stress and to improve immune and stress responses. There were no indications that the Se requirement exceeded the current recommendation of $0.3 \mathrm{mg} \mathrm{kg}[\mathrm{sup}]-1$ [sup]. 


\section{Introduction}

The shift from marine to plant based ingredients in fish feeds leads to changes in dietary concentrations and bioavailability of several nutrients. So far, research on plant based diets for Atlantic salmon has mainly focused on balancing the amino acid profile and reducing the amounts of antinutrients (Espe et al. 2006; Espe et al. 2007; Krogdahl et al. 2005), while micronutrients have received far less attention. In the present study, two feeding experiments were conducted on salmon, one with parr in freshwater and one with post-smolt in seawater, using a basic diet containing $10 \%$ fishmeal and $3.5 \%$ fish oil of the total recipe, in addition to plant based protein and lipid sources. A nutrient premix (NP), containing potentially critical micronutrients, amino acids, taurine and cholesterol, was added at graded levels to this diet and health indicators and biomarkers were used to estimate optimal supplementation of the different nutrients. Hemre et al. (2016) presents data on general fish performance, retention of macronutrients, B-vitamins and amino acid metabolism. Data on selected minerals and vitamin A, D and $\mathrm{K}$ are presented by Lock et al. (in prep). The present publication is related to antioxidant nutrients and redox regulation.

Vitamin $\mathrm{E}$ is the general term for a group of lipid soluble antioxidants, tocopherols and tocotrienols, where $\alpha$-tocopherol ( $\alpha-\mathrm{TOH}$ ) has the highest biological activity (United States Pharmacopeia 1993). $\alpha$-TOH is selectively retained in the body of mammals (Kayden \& Traber 1993; Rigotti 2007) and Atlantic salmon (Hamre 2011; Hamre et al. 1998), possibly due to a liver TOH binding protein, with high affinity for this isomer (Kayden \& Traber 1993; Yoshida et al. 1992). Vitamin E breaks the chain of lipid peroxidation by reducing fatty acid peroxide radicals, preventing oxidation of new fatty acids (Buettner 1993). It takes approximately 3 months for Atlantic salmon parr to adjust their body concentration of $\alpha$-TOH to the dietary concentration and there is a linear relation between dietary and whole body concentrations when dietary $\alpha-\mathrm{TOH}$ ranges between 0 and $300 \mathrm{mg} \mathrm{kg}^{-1}$. The slope is quite reproducible between experiments, at approximately 0.25 between fish concentration on wet weight and feed concentration on dry weight (Hamre et al. 1997; Hamre \& Lie 1995). Vitamin E is added as $\alpha$-tocopheryl acetate ( $\alpha$-TOAc) in fish feed, thereby protected against oxidation. The requirement is highly variable, in rainbow trout (Oncorhynchus mykiss) dietary requirements between 5 and $100 \mathrm{mg} \mathrm{kg}^{-1}$ have been reported, dependent on dietary composition and experimental conditions. Factors that affect the vitamin E requirement are dietary PUFA, vitamin C and Se concentrations and oxidized feed (Hamre 2011). Furthermore, the estimated requirement varies with the response variable used. Hemoglobin concentration is a sensitive indicator of overall health and growth performance while indicators of immune function respond at higher dietary levels of vitamin $E$ and will often give very high requirement assessments (Hamre 2011). In the present 
study, $\gamma-\mathrm{TOH}$ is used as a representative of the non- $\alpha-\mathrm{TOH}$, since it is often present in plant oils at high concentrations.

In classical nutrition, vitamin C (ascorbic acid, Asc) has a well defined role as a cofactor for the enzymes catalyzing the hydroxylation of proline and lysine, necessary for formation of collagen and bone matrix (Barnes \& Kodicek 1972; Gould et al. 1960; Terova et al. 1998). The function of Asc is to keep the iron present at the enzymes' active site in the reduced state (Meister 1994). More generally, Asc is a watersoluble antioxidant, it scavenges free radicals and probably participates in recycling oxidized vitamin $\mathrm{E}$ (Hamre et al. 1997; Tappel 1962). The resulting Asc radical or dehydroascorbic acid can in turn be reduced by glutathione (GSH) and ultimately by NADPH produced in energy metabolism (Mrtensson \& Meister 1991). It was not until stable and fully bioavailable forms of vitamin C were developed that meaningful requirement studies in fish could be designed (Woodward 1994). Sandnes et al. (1992) performed one of the first of such studies in Atlantic salmon using Ca ascorbate-monophosphate (AP). They found a minimum dietary requirement, based on growth, mortality and skin and backbone hydroxyproline concentration, of 10-20 mg kg-1. Severe deficiency symptoms appeared first after 18 weeks of feeding the non-supplemented diet. Concentration of Asc in the liver was linearly related to dietary AP up to $160 \mathrm{mg}$ $\mathrm{kg}^{-1}$ Asc equivalents. The appearance of vitamin C deficiency symptoms depends on the dietary concentration of vitamin $\mathrm{E}$ and is probably affected by other variations in the experimental conditions as well (Dabrowski et al. 2004; Gabaudan \& Verlhac 2001; Sandnes et al. 1992). It is common for several fish species that dietary Asc required for maximum body or tissue storage surpasses the requirement levels for growth, survival and hydroxyproline concentrations (NRC 2011). Furthermore, immune response indicators are stimulated by Asc levels far above conventional requirements, which also protect against stress (Trichet 2010; Waagbø 1994; Waagbø 2006).

Selenium (Se) is an essential trace element inserted in selenocysteine (Sec), situated at the active site of Se dependent proteins, termed selenoproteins (Brigelius-Flohe 1999). The selenoproteins can be grouped in stress-related and housekeeping proteins, the first group responds readily to dietary Se and includes glutathione peroxidase (GPX) 1 and 3 (Penglase et al. 2014). In mammals, the dietary Se level at which GPX1 activity and gene expression level off, is used as an indicator of the Se requirement (Sunde et al. 2009; Weiss et al. 1996; Weiss et al. 1997). GPX1 activity in rainbow trout plasma followed a similar trajectory to that in mammalian tissues and leveled off at dietary Se levels (given as $\mathrm{Na}_{2} \mathrm{SeO}_{3}$ ) between 0.15 and $0.38 \mathrm{mg} \mathrm{kg}^{-1}$ (Hilton et al. 1980). However, in zebrafish, maximum growth correlated with minimum whole body GPX1 activity and mRNA expression at $0.3 \mathrm{mg} \mathrm{kg}^{-1}$ dietary Se. Dietary Se above this 
110 level reduced growth and increased GPX1 activity and expression (Penglase et al., 2014). This may indicate 111 that the relation between GPX1 and Se requirement is different in fish and mammals. There was a linear 112 relationship between dietary Se in the range 0.1 to $1.0 \mathrm{mg} \mathrm{kg}^{-1}$ and whole body Se concentrations in the 113 zebrafish study (Penglase et al. 2014).

114 The cellular redox environment affects the cell's fate because gene expression, protein function and 115 molecular pathways are often redox sensitive (Go \& Jones 2013; Jones \& Sies 2015; Kirlin et al. 1999). The 116 key mechanism is that protein cysteine residues switch between oxidized and reduced states 117 corresponding to active and inactive states of the involved proteins (redox switches). An example is that 118 a more oxidized cellular environment induces a redox switch that releases the nuclear factor-erythroid 2119 related factor 2 (NFE2L2) transcription factor from a complex with another protein, KEAP1. Once released, 120 NFE2L2 induces the transcription of at least 50 mammalian genes; many of which code for antioxidants, 121 thiol oxidoreductases and glutathione synthesis/recycling genes; that are involved in maintaining the 122 redox balance and/or are involved in redox signaling (reviewed by Ma 2013). Cellular redox homeostasis 123 is thought to be maintained by redox couples that act as electron buffers due to their ability to readily 124 cycle between oxidized and reduced forms (Jones \& Sies 2015). The major redox couples are 125 reduced/oxidized glutathione (2GSH/GSSG), cysteine (2Cys/CySS) and thioredoxin ( $\left.\operatorname{Trx}(\mathrm{SH})_{2} / \operatorname{TrxSS}\right)$ 126 (Huseby et al. 2009) and the related redox potential (E) is proportional to the ratio between the (reduced) ${ }^{2}$ 127 and oxidized forms of the redox couples, according to the Nernst Equation. GSH/GSSG is present in cells 128 in high concentrations. It may therefore be the most important cellular redox couple and is used as an 129 indicator of tissue redox state in the present study. The glutathione based redox potential seems to be 130 strictly regulated in Atlantic salmon (Hamre et al. 2010b). A hypothesis of the present study is therefore 131 that GSH/GSSG concentrations and $E_{G S H}$ are stable in healthy fish and can be used as indicators of fish 132 welfare during the growth phase in salmon. On the other hand, the 2GSH/GSSG redox couple and many 133 genes coding for proteins that maintain the cellular redox system are dynamically regulated during fish 134 embryonic and larval development (Hamre et al. 2014; Penglase et al. 2015; Skjærven et al. 2013; Timme135 Laragy et al. 2013).

136 Here we present data on antioxidant nutrients and redox regulation of two feeding trials (freshwater and 137 seawater) with graded NP levels. Tissue concentrations and retention of vitamin C, E and Se, traditionally 138 viewed as the main antioxidant nutrients, as well as effects of a graded nutrient premix on tissue 139 GSH/GSSG concentrations and the related redox potentials, were analyzed. We have also measured the 140 expression of some central genes for regulation of redox homeostasis in the liver; the transcription factor 
141 nfe2/2, cuznsod, mnsod, cat, gpx1 and gpx3 which metabolize superoxide anions and $\mathrm{H}_{2} \mathrm{O}_{2}$, gclc which 142 translates into the rate limiting protein in GSH synthesis, and $g 6 p d$ and gr involved in keeping glutathione 143 in the reduced state.

145

146 
147

148

149

150

151

152

153

154

155

156

157

158

159

160

161

162

163

164

165

166

167

168

169

170

171

172

173

174

175

176

\section{Materials and methods}

\subsection{Experimental diets}

The seven experimental diets were produced at Biomar Technology Centre (Denmark), as described in Hemre et al. (in prep). All diets contained the same basal mixture of ingredients $(10.4 \%$ marine protein ingredients and $3.5 \%$ fish oil of the whole receipt, the rest plant ingredients, Table 1 ). A nutrient premix (NP) was added in graded amounts, replacing some of the field peas in the formulation. Phosphate, lysine, threonine and choline were added to all diets in equal amounts. An antioxidant mixture to protect the feed during production, and yttrium for later digestibility measurements were also added to all diets. Diet acronyms were as follows: ONP had no addition of the micronutrient premix, then the NP was added in graded amounts to the six diets called 25NP, 50NP, 100NP, 150NP, 200NP and 400NP. The general idea was that the 100NP diets should contain $100 \%$ of the assumed requirement, achieved by addition of the nutrient premix to the basal diet (based on available data, primarily for rainbow trout (NRC 2011) for each nutrient). However, some nutrients such as $\alpha$-tocopherol and Se were already present at or above expected minimum requirements in the basal diet, but these were added in the NP to achieve increasing levels in the 7 diets and to examine if higher requirements could be assessed. The 25NP diet contained 0.25 times the NP from the 100NP diet, while the 400NP contained 4 times the NP from the 100NP diet. As all nutrients were also present in the diet ingredients to some extent (not only contributed by the NP), the 400NP diet would never have 4 times higher content than the 100NP diet, and the fold difference would vary depending on the contribution from the NP versus the diet ingredients for each nutrient. The NP contained vitamin $D_{3}$, $\alpha$-tocopheryl acetate, vitamin $K_{3}$, vitamin $A_{1}$, ascorbyl monophosphate, vitamin $B_{6}$, biotin, cobalamin, folate, pantothenic acid, riboflavin, thiamine, niacin, Se (as inorganic sodium selenite), iodine, copper, cobalt, manganese, zinc, crystalline DL-methionine, and taurine. Crystalline Lhistidine and cholesterol were also added in graded amounts. The analyzed composition of the diets can be found in Table 2, including proximate composition and contents of the micronutrients focused in this presentation.

\subsection{Feeding trials}

Both feeding trials were conducted in accordance with Norwegian laws and regulations concerning experiments with live animals, which are overseen by the Norwegian Food Safety Authority. 
177 Trial 1: The trial with parr in freshwater took place at the Institute of Marine Research (Matredal, $61^{\circ} \mathrm{N}$,

178 Western Norway). The salmon were hatched in February, and in June the salmon parr were randomly 179 distributed in fifteen 400 litre $\left(1 \times 1 \times 0.4 \mathrm{~m}^{3}\right)$ experimental tanks and acclimated for 1 week while being fed 180 a commercial feed (Ewos). The trial commenced on July $3^{\text {rd }}$, with duplicate tanks for each diet with the 181 exception of NP100 that was run in triplicates. Each tank contained 100 fish with mean initial body weight of $18.3 \pm 2.2 \mathrm{~g}$. The fish were fed ad libitum with continuous feeding from automated feeders during night and day. However, care was taken to limit overfeeding, due to uncertainties in the collection of uneaten feed at such a small pellet size. Collection and weighing of uneaten feed was conducted daily at 13:00, with the exception of weekends. The fish were exposed to continuous light, and oxygen saturation was monitored on a regular basis and was never below 75\%. The fish were reared in freshwater, but with seawater added as a buffer, creating a salinity of 1.1 to $1.3 \mathrm{~g} \mathrm{~L}^{-1}$.The temperature was kept constant throughout the experiment, at $12.4{ }^{\circ} \mathrm{C}(\mathrm{SD} \pm 0.7)$. The total duration of the feeding trial was 12 weeks, e.g. 84 days.

Trial 2: Post-smolt Atlantic salmon were randomly distributed among fifteen sea cages $(5 \mathrm{~m} \times 5 \mathrm{~m} \times 5 \mathrm{~m}$; $125 \mathrm{~m}^{3}$; 150 fish per cage) at Gildeskål Research Station, GIFAS, Gildeskål kommune, Norway (67²N, Northern Norway). Prior to the start of the trial, fish were acclimated to the environmental conditions for two weeks, the feeding trial started in January 2013. At start, the average fish weight was $228 \pm 5 \mathrm{~g}$ and during the 157 day feeding period the fish more than doubled in weight. As in standard aquaculture practice, fish were reared under $24 \mathrm{~h}$ light regime before the start of the trial and during the first 3 months of the experiment. Cages were illuminated by four 400W IDEMA underwater lights that were positioned at the center of each block of four cages at a depth of three meters. Fish were hand-fed to satiation two times daily and feed intake was recorded for each sea cage. Total feed intake and mortality were recorded daily. Water temperature, salinity and oxygen saturation over the course of the trial varied from 4.1 (January) to $10^{\circ} \mathrm{C}$ (June), 30-34.2 $\mathrm{g} \mathrm{L}^{-1}$, and 8.7-12.2 $\mathrm{mg} / \mathrm{L}$, respectively.

201

202

\subsection{Sampling}

203

Fish were anesthetized (Benzoak ${ }^{\circledR}$ VET, $0.2 \mathrm{ml} / \mathrm{L}$, ACD Pharmaceuticals, Leknes, Norway) and killed by a blow to the head. In Trial 1 , the fish in each tank were bulk weighed for total biomass at each sampling point and body weight and forklength were measured on individual fish, 5-44 fish depending on sampling 
207 (mid sampling 42 fish per cage, end sampling 34 fish per cage). In both trials, blood was drawn from the

208 caudal vein (Vena caudalis) by means of a heparinized medical syringe from 8 fish per tank or cage, before 209 organs were dissected and kept as individual samples. Pooled organ samples based on 10 fish for each 210 tank or cage (liver, gills, muscle) were frozen on dry ice and later homogenized, while individual organ 211 samples were flash frozen in liquid nitrogen.

212

\subsection{Chemical analysis of diets, whole fish and organs}

214

215

216

217

218

219

220

221

222

223

224

225

226

227

228

229

230

231

232

233

234

235

236

Multi-element determination in the feed and tissue samples was done by ICP-MS (inductively coupled plasma mass spectrometry) (Julshamn et al. 1999). HPLC was used for determination of ascorbic acid (Mæland \& Waagb $\varnothing$ 1998) and tocopherols analysed according to (CEN 1999). TBARS was analyzed according to Hamre et al. (2001). For the analysis of total (tGSH) and oxidised (GSSG) glutathione, supernatants were prepared from samples using a commercial kit (Prod. No. GT40, Oxford Biomedical Research, Oxford, UK) before analysed at $405 \mathrm{~nm}$ in a microplate reader (iEMS Reader Ms, Labsystems, Finland) as described by Hamre et al. (2014).

\subsection{Gene expression analysis}

Total RNA was purified from frozen liver using the EZ1 RNA Universal Tissue Kit on the BioRobot ${ }^{\bullet}$ EZ1 (Qiagen, Hilden, Germany), including the optional DNase treatment step in the protocol. Homogenisation in QIAzol lysis reagent from the kit was performed on the bead grinder homogeniser Precellys 24 (Bertin Technologies, Montigny-le-Bretonneux, France) for 3x10 sec at 6000rpm. Quantity and quality of RNA were assessed with the NanoDrop ND-1000 UV-Vis Spectrophotometer (NanoDrop Technologies, Wilmington, DE, USA) and a selection of samples were evaluated on the Agilent 2100 Bioanalyzer (Agilent Technologies, Palo Alto, CA, USA), with the 6000 Nano LabChip ${ }^{\circledR}$ kit (Agilent Technologies, Palo Alto, CA, USA). ). Average RNA integrity number (RIN) for the samples in Trial 1 (39 samples) was $9.4 \pm 0.1$ (mean \pm SEM, $n=24)$, in Trial 2, (90 samples): $9.5 \pm 01$ (mean $\pm S E M, n=11$ )

Reverse transcription (RT) was performed on a GeneAmp PCR 9700 (Applied Biosystems, AB) using the $\operatorname{TaqMan}^{\circledR}$ reverse transcriptase kit with oligo(dT) primers (Applied Biosystems). Primer sequences are given in Table 3. Samples were run in duplicate ( $500 \mathrm{ng}, \pm 5 \%$ ), in addition to a six point dilution curve in triplicate (1000 to $31.25 \mathrm{ng}$ ), non-template and non-amplification controls. Real-time PCR amplification and analysis were performed on a LightCycler 480 Real-time PCR system (Roche Applied Science, Basel, 
237 Switzerland) with SYBR ${ }^{\bullet}$ Green I Mastermix (Roche Applied Science). Pipetting of plates was done using 238 a Biomek $^{\circ} 3000$ Laboratory automation workstation (Beckman Coulter, Fullerton, USA). Thermal cycling 239 was done for 45 cycles of $10 \mathrm{sec}$ at each of $95^{\circ} \mathrm{C}, 60^{\circ} \mathrm{C}$ and $72^{\circ} \mathrm{C}$ (basic programme from Roche), followed 240 by melting analysis to confirm that only one product is present.

241 Cycle threshold ( $\mathrm{Ct}$ ) -values were calculated using the second maximum derivative method in the 242 Lightcycler ${ }^{\circ}$ software. Amplification efficiency was determined using the dilution curves with the formula $243 E=10^{\wedge}(-1 /$ slope), with the slope of the linear curve of Ct-values plotted against the log-dilution (Higuchi et 244 al. 1993). Normalization to the reference genes and data analysis was conducted with GenEx 4.3.5 (MultiD 245 Analyses AB, Gothenburg, Sweden) or with the geNorm applet (Vandesompele et al., 2002).

\subsection{Calculations}

Nutrient retention $=[($ final biomass $\times$ final nutrient concentration $)-($ initial biomass $\times$ initial nutrient concentration) $\times 100 /$ (Total feed intake $\times$ nutrient concentration in feed).

The two-electron half-cell reduction potential of the 2 GSH/GSSG redox-couple was calculated according to the Nernst equation:

$E_{h}=E^{0 \prime}-R T / n F \ln \left([G S H]^{2} /[G S S G]\right)$

253

254

255

256

257

258

259

260

261

262

263 264

where the GSH and GSSG concentrations are in $M$ and $E_{h}$ is given in volts. $E^{0 \prime}$ is the standard reduction potential at $\mathrm{pH} 7$ and $25^{\circ} \mathrm{C}$ and was assumed to be $-0.240 \mathrm{~V}$ (Kemp et al. 2008; Schafer \& Buettner 2001). The measurements are the average of whole organs and do not take into account that the reduction potential varies between cell types, and between organelles within the cells (Kemp et al. 2008; Morgan et al. 2013; Schafer \& Buettner 2001).

\subsection{Statistical analyses}

GraphPad Prism (ver. 6.05) was used for the regression analyses. For the individual nutrients, the $x$-axis represented analyzed dietary concentrations, while for glutathione and gene expression data the $\mathrm{x}$-axis represented added NP. Since the nutrient concentrations in the 400\%NP diet were outliers in Trial 2, the value of this diet was recalculated to $239 \% \mathrm{NP}$, the mean of the concentrations of $\alpha-\mathrm{TOH}, \mathrm{Asc}$ and Se. The best fit of the data after comparing different functions moving from simple to more complex relationships, 
265

266

267

268

269

270

271

272

273

274

275

276

277

278

279

280

281

282

283

284

285

286

287

288

289

290

291

292

293

294

was used. In figures with first order polynomials, $p$ indicates the probability that the slope is equal to 0 . In figures with second order fits, $p$ gives the probability that the first order equation fits the data better than the second order equation. The logarithmic equation was applied for vitamin $C$ retention in Trial 2 and $p$ indicates the probability that a second order polynomial has a better fit than the logarithmic function. A function for overall comparison of slopes and intercepts of datasets fitted to linear equations, was used for comparison of data between Trials 1 and 2. The software also has a function for detecting outliers which was used for the data on muscle GSH/GSSG in post-smolts and on the gene expression data.

Correlation analyses of gene expression was performed using the software Statistica (ver. 11, Statsoft Inc., Tulsa OK) and PCA plots were produced in Sirius (ver 8.1, Pattern Recognition Systems AS, Bergen Norway).

\section{Results}

Fish performance is reported in detail by Hemre et al. (2016). Briefly, fish in Trial 1 grew from an initial weight of $18.3 \mathrm{~g}( \pm 2.2)$ to a range of $78.6 \mathrm{~g}( \pm 1.9)$ to $87.3 \mathrm{~g}( \pm 4.5)$. Both fish growth and protein retention increased with increasing dietary NP, while lipid retention decreased, together with liver index and viscera-somatic index. In trial 2, initial fish size was $228 \mathrm{~g}( \pm 4.2)$ and average final weight was $482 \mathrm{~g}( \pm$ 17). There was no effect of the NP on growth or protein and lipid retention in this trial. Survival was high in both trials, close to $100 \%$, and with no difference between diet groups.

The dietary concentrations of $\alpha-\mathrm{TOH}, \mathrm{Asc}$ and Se (Figure S1) were well fitted to first order polynomials in Trial $1\left(R^{2}>0.98\right)$. In Trial 2, the diet designated $400 \%$ was an outlier, while the other diets showed a good fit to a linear equation $\left(R^{2}>0.97\right)$. The diet planned to contain $400 \% N P$ in trial 2 was recalculated to contain $239 \% \mathrm{NP}$, based on the nutrient analyses of the diets. Gamma-TOH level was similar in all diets, as it was only derived from the feed ingredients (Figure S1). The dietary concentrations at 100\% NP were 118 and $141 \mathrm{mg} \mathrm{kg}^{-1}$ for $\alpha-\mathrm{TOH}, 67$ and $63 \mathrm{mg} \mathrm{kg}^{-1}$ for Asc and 0.62 and $0.79 \mathrm{mg} \mathrm{kg}^{-1}$ for Se, in Trials 1 and 2, respectively. At $0 \% \mathrm{NP}$ the dietary concentrations were 48 and $76 \mathrm{mg} \mathrm{kg}^{-1}$ for $\alpha-\mathrm{TOH}, 4.7$ and $<5.5 \mathrm{mg} \mathrm{kg}^{-}$ ${ }^{1}$ for Asc and 0.42 and $0.47 \mathrm{mg} \mathrm{kg}^{-1}$ for Se (Table 2).

There was a linear relationship between dietary and whole body concentrations of $\alpha$-TOH in Trial 1 $\left(R^{2}=0.94 ; p(\right.$ slope $=0)<10^{-4}$; Figure 1$)$. In Trial 2, a second order polynomial fitted the data better than a first order polynomial ( $p=0.03$ ). The range of whole body concentrations was between 20 and $60 \mathrm{mg} \mathrm{kg}^{-1}$ in Trial 1 and between 30 and $50 \mathrm{mg} \mathrm{kg}^{-1}$ in Trial 2. Whole body $\mathrm{y}^{-\mathrm{TOH}}$ concentration varied between 5 
295

296

297

298

299

300

301

302

303

304

305

306

307

308

309

310

311

312

313

314

315

316

317

318

319

320

321

322

323

324

325

and $10 \mathrm{mg} \mathrm{kg}^{-1}$, with a significant positive slope in Trial $1(\mathrm{p}=0.02)$ and no effect of diet in Trial 2 (Figure 1). Whole body Asc concentration followed a second order polynomial in both trials (Trial $1, R^{2}=0.92$, $p<0.0001$; Trial $2, R^{2}=0.88, p=0.016$ ). Whole body concentration plateaued at a dietary concentration of Asc of $\mathrm{mg} \mathrm{kg}^{-1} \mathrm{DM}$ and a whole body concentration of $39.5 \mathrm{mg} \mathrm{kg}^{-1}$ in Trial 1. In Trial 2, the plateau was reached at dietary and whole body concentrations of 100 and $14 \mathrm{mg} \mathrm{kg}^{-1}$, respectively. Whole body Se showed a linear relationship with the dietary concentration in both trials $\left(R^{2}>0.93, p(\right.$ slope $\left.=0)<10^{-4}\right)$. The diet dependent whole body concentration was significantly higher in Trial 2 than in Trial $1\left(p<10^{-4}\right)$.

The retention of $\alpha-\mathrm{TOH}$ was not affected by diet in Trial 1 and followed a second order polynomial in Trial $2(p=0.02)$ with the highest retentions at intermediate dietary $\alpha$-TOH concentrations (Figure 2). Diet did not affect the retention of $\mathrm{\gamma}-\mathrm{TOH}$ in Trial 1 , while increasing the NP in Trial 2 had a negative effect on $\gamma$ TOH retention $(p<0.004)$. The range of retention of both $\alpha$ - and $y-\mathrm{TOH}$ was $20-30 \%$. In Trial 1 , retention of Asc ranged from $11-42 \%$ and was negatively linearly related to dietary $\operatorname{Asc}\left(R^{2}=0.34, p(s l o p e=0)=0.02\right)$. In Trial 2, vitamin C retention was negative at dietary levels below $63 \mathrm{mg} \mathrm{kg}^{-1}$ and max retention was $16 \%$ at $89 \mathrm{mg} \mathrm{kg}^{-1}$. A logarithmic function was found to have the best fit to the data $\left(R^{2}=0.92\right)$. Diet did not affect retention of Se, which ranged from 20 to 30\%. The retention of Se was higher in Trial 2 than in Trial 1 $\left(p<10^{-4}\right)$.

GSH and GSSG concentrations were measured in muscle (Figure 3) and liver (Figure 4). In muscle in Trial 1, GSH concentrations ranged from 100 to $200 \mu \mathrm{mol} \mathrm{kg}{ }^{-1}$, GSSG ranged from 0 to $0.4 \mu \mathrm{mol} \mathrm{kg}^{-1}$ with no effect of diet. There was a tendency that the resulting glutathione based redox potential followed a second order polynomial at dietary NP below $150 \%$, so that the tissue became transiently more reduced at supplementation of $25-100 \%$ NP than at $150-400 \%$ NP $(p=0.058)$. The redox potential of muscle in Trial 1 ranged from -240 to $-190 \mathrm{mV}$. In Trial 2, muscle GSH and GSSG concentrations ranged from 43 to 80 and 0 to $0.4 \mu \mathrm{mol} \mathrm{kg}{ }^{-1}$, respectively, and the redox potential from -170 to $-220 \mathrm{mV}$, with no effect of diet. The muscle GSH/GSSG concentrations in these fish were close to quantification limits and some of the data points were removed as outliers. Muscle GSH concentration was higher $(p<0.0001)$, the redox potential lower $(p=0.002)$ and GSSG concentration similar in Trial 1 compared to Trial 2. In the liver, GSH, GSSG and the glutathione based redox potential were not affected by the diet, however there was a tendency towards a significant second order fit to the data on liver redox potential in Trial 1 ( $p=0.066)$, implicating a higher redox potential in fish fed diets with intermediate NP additions. Liver GSH concentration was higher $(p<0.0001)$, while GSSG concentration $(p=0.01)$ and the redox potential $(p<0.0001)$ were lower in Trial 1 than in Trial 2. 
326 Muscle TBARS (Figure 5) was negatively correlated to NP addition in both trials ( $p=0.004$ in Trial $1, p=0.03$

327 in Trial 2) and the absolute level was similar in the two trials ( $p=0.09)$.

328 Expression of redox dependent genes was measured in the liver of individual salmon in both trials. PCA 329 plots showed that the dietary groups were not well separated according to expression of the redox related 330 genes (Figure 6). However, in Trial 1 there was a tendency to grouping of samples related to dietary 331 supplementation of NP, with NP supplementation correlating negatively to $g 6 p d, g c l c, g p x 1$ and $g r(-$ $\left.3320.38<R^{2}<-0.43\right)$ and positively to $g p \times 3\left(R^{2}=0.39\right)$. Gr showed the most covariation with other genes and 333 correlated to $g 6 p d, g p \times 1$ and $g c l c$ at $0.79>\mathrm{R}^{2}>0.49$ and to mnsod and cuznsod at $\mathrm{R}^{2}=0.39$ and 0.34 , 334 respectively. Gr was also correlated to $n f e 2 / 2\left(R^{2}=0.52\right)$, cat was not correlated to the other genes while gpx3 was negatively correlated to the other genes, significant for $g 6 p d\left(R^{2}=-0.33\right)$. In Trial 2, diet was correlated to cuznsod, mnsod and cat $\left(0.39<\mathrm{R}^{2}<0.24\right)$. The expression of $g r, g 6 p d, g p x 1$ and $g c / c$ comprised one distinct group and mnsod, cat and cuznsod another. Gr correlated with $g 6 p d$, gpx1 and gclc at $0.67>R^{2}>0.37$, while gr correlation to mnsod, cat and cuznsod was $0.32>R^{2}>0.25$. Gpx3 and $n f e 2 / 2$ were not significantly correlated to the other genes.

Relations between diet and gene expression are given in Figure S1. In Trial 1, increasing supplementation of NP gave a reduction in gclc, g6pd, gpx1, gr and mnsod expression, while nfe2/2, cat and cuznsod expression were unaffected by diet. In Trial 2, data on $n f e 2 / 2$ and gclc were fitted to second order polynomials and had higher expression at intermediate NP supplementation. Gpx1 showed the best fit when using a third order polynomial with peak expression at 50 and 100\% NP inclusion. Gpx3 had higher expression at low NP inclusion, while mnsod expression increased with increasing NP. Cuznsod expression was slightly lower at intermediate NP inclusion than at high and low inclusion, while G6pd and $g r$ expression were unaffected by the diet. Average expression of gpx1, gpx3 and mnsod was higher in Trial 2 than in Trial 1 ( $p<0.0002$ ). Increasing NP inclusion had opposite effects on mnsod expression in the two trials, which decreased in Trial $1(p=0.04)$ and increased in Trial $2(p=0.002)$.

\section{Discussion}

The present study showed differences in redox status between parr and post-smolts and effects of supplementation of the nutrient premix (NP) on redox regulation. However, there were no clear 
356 E and Se and that the experimental periods were too short for fish of these body sizes to develop vitamin

357 C deficiency symptoms. The basal feed contained less than $5.5 \mathrm{mg} \mathrm{kg}^{-1} \mathrm{Asc}$, which is below the minimum 358 requirement in Atlantic salmon of $10-20 \mathrm{mg} \mathrm{kg}^{-1}$, however it took 18 weeks to deplete first-feeding Atlantic 359 salmon for Asc (Sandnes et al. 1992) and a longer period of time may be needed to deplete larger fish 360 sizes as the post-smolts. The final concentrations of $\alpha$-TOH and Se in the basal feed were at or above 361 minimum requirements at approximately 50 and $0.3 \mathrm{mg} \mathrm{kg}^{-1}$ diet, respectively (NRC 2011). Plant oils often 362 have high concentration of tocopherols, however tocopherols are unstable during feed processing and 363 storage and concentrations could vary considerably in the finished feeds (Hamre et al. 2010a; Olsvik et al. 364 2011). Se concentrations in plant ingredients vary according to Se concentration in soil (Alfthan et al. 365 2015). So even if $\alpha-\mathrm{TOH}$ and Se may be sufficient in some plant ingredients, they should be added to fish 366 feeds to ensure safe supplementation. Commercial fish feeds are commonly supplemented with higher 367 levels of antioxidant nutrients than the minimum requirements given by NRC (2011), which will protect 368 the fish in periods with oxidative stress, such as high water temperatures (Martinez-Alvarez et al. 2005) 369 elevated water oxygen levels (Lygren et al. 2000), vaccination (Lygren et al. 2001) and disease (Trichet 370 2010; Waagb $\varnothing$ 2006). Accordingly, the diets with $100 \%$ NP used in this study, contained $118-141 \mathrm{mg} \mathrm{kg}^{-1}$ a-TOH, 63-67 $\mathrm{mg} \mathrm{kg}^{-1}$ Asc and 0.62-0.79 $\mathrm{mg} \mathrm{kg}^{-1} \mathrm{Se}$, respectively.

372

The most sensitive biomarker of vitamin E deficiency in salmonids is lowered hemoglobin ( $\mathrm{Hb}$ ) concentration (Hamre 2011). There was a slight positive correlation between NP addition and Hb concentration in fish from Trial 1 (p(slope=0)=0.03)(Hemre et al., in prep), however, the slope was not significantly different from 0 after omitting the 400\% NP group $(p=0.44)$, so fish fed the diets with low NP supplementation were clearly not vitamin E deficient. In Trial 2, there was no effect of diet on $\mathrm{Hb}$ (Hemre et al. 2016). Hamre and Lie (1995) found that mortality due to vitamin E deficiency commenced at whole body levels of $\alpha-\mathrm{TOH}$ of $5 \mathrm{mg} \mathrm{kg}^{-1}$ wet weight, while the whole body concentration in fish fed the basal diet in this study were 18 and $32 \mathrm{mg} \mathrm{kg}^{-1}$ in Trials 1 and 2, respectively. Accordingly, none of the fish groups in this study experienced vitamin E deficiency, even though the low level of vitamin $C$ in the diet without NP would make the fish more susceptible to low dietary vitamin E (Hamre et al. 1997).

The diets were fed for 12 and 22 weeks in Trials 1 and 2, respectively. The twelve weeks feeding period in Trial 1 should just be enough for the fish to adjust to the $\alpha$-TOH concentrations of the diet according to previous reports (Hamre 2011; Hamre \& Lie 1995). However, the slope of whole body concentration to dietary concentration was lower (0.13 vs 0.25$)$ and the intercept with the y-axis was higher (15.6 vs 0 ) 
387 been obtained (Hamre 1995). A relation of body to dietary concentrations of $\alpha$-TOH has until now only 388 been measured in very young fish and these relationships were always linear (Hamre et al. 1997; Hamre $389 \&$ Lie 1995). In post-smolts in the present study, the relationship followed a second order polynomial. It 390 is possible that uptake of $\alpha-\mathrm{TOH}$ is changing over development, moving from a strict linear relationship 391 just after first-feeding to a saturable mechanism at later stages. If this is the case, the diet $100 \%$ NP with $392141 \mathrm{mg} \mathrm{kg}^{-1} \alpha-\mathrm{TOH}$ would be sufficient to saturate the system, while supplementation above this gave a decreased retention. In summary, supplementing commercial diets with above $150 \mathrm{mg} \mathrm{kg}{ }^{-1} \alpha-\mathrm{TOH}$ is recommended to promote fish health and welfare. A fish feed surveillance program run by NIFES in 2015 reported 185-320 mg kg-1 $\alpha$-TOH in 18 commercial salmon feeds, while two feeds contained as high as $570 \mathrm{mg} \mathrm{kg}^{-1}$ (NIFES unpublished results) A variable part of this $\alpha-\mathrm{TOH}$ would have been derived from the feed ingredients. One have to take into account that $\alpha-\mathrm{TOH}$ in the feed ingredients is in the free form, which is easily broken down in salmon intestine and therefore has quite low retention (Meland 1995). It is therefore a risk involved in including ingredient contribution when deciding dietary $\alpha$-TOH 400 supplementation.

401

The non- $\alpha-\mathrm{TOH}$ s cannot substitute for $\alpha-\mathrm{TOH}$, because of their lower biological activity (Hamre 2011; Kayden \& Traber 1993), however they may have specific biological functions in cell signaling (Golli \& Azzi 2010; Wallert et al. 2014). In both trials of this study, the retentions of $\alpha$ - and $\gamma$-TOH were similar at 20$30 \%$. Due to lower biological activity, retention of $\mathrm{y}-\mathrm{TOH}$ should be lower than $\alpha-\mathrm{TOH}$, but the result can be explained by similar retention of $\alpha$ - and $\gamma-\mathrm{TOH}$ in muscle and adipose tissue, which are the main constituents of the whole body sample. Retention of $\mathrm{y}-\mathrm{TOH}$ in other vital organs of salmon, such as gonads, intestine, and gills, is less than $30 \%$ compared to $\alpha$-TOH (Hamre \& Lie 1997).

The whole body concentration of Asc followed a second order equation with respect to Asc supplementation in both trials. It is well known that tissue levels of Asc level off at dietary supplementation that is much higher than the levels where traditional deficiency symptoms are displayed

411 (Gabaudan \& Verlhac 2001; Waagb $\varnothing$ \& Sandnes 1996). Since Asc above this minimum requirement has 412 positive effects on immune function, stress resistance and reproduction (Gabaudan \& Verlhac 2001; 413 Waagbø 1994; Waagb $\varnothing 2006)$, it may be fruitful to supplement more of the vitamin. The whole body concentration levelled off at a dietary Asc concentration of $190 \mathrm{mg} \mathrm{kg}^{-1}$ in Trial 1 and at 63-89 mg kg-1 in Trial 2. The maximum body concentration of Asc in fish from Trial 2 was approximately $30 \%$ of that in fish 416 from Trial 1. While the data from Trial 1 follow the expected trajectory based on the literature, the fish in 417 Trial 2 seems to have had an extraordinary high consumption of Asc, with negative retention for fish 
418 supplemented below $63 \mathrm{mg} \mathrm{kg}^{-1}$ and maximum retention of $16 \%$ at higher supplementation, compared to $419 \max 42 \%$ retention in Trial 1.

420 There is probably an optimal ratio between supplementation of $\alpha$-TOH and Asc, based on the hypothesis

421 that vitamin E is recycled by vitamin C. A buildup of tocopheroxyl radicals would occur if too little vitamin

$422 \mathrm{C}$ is present to recycle it, which would have a pro-oxidant effect on the tissues (Hamre et al. 1997). An

423 indication of this principle is the higher mortality due to vitamin C deficiency in fish fed 300 compared to $424150 \mathrm{mg} \mathrm{kg}^{-1}$ vitamin $\mathrm{E}$ (Hamre et al. 1997). Another indication is that vitamin $\mathrm{E}$ and $\mathrm{C}$ in tissues from 425 copepods and wild Ballan wrasse are 100 and $500 \mathrm{mg} \mathrm{kg}^{-1}$ dry matter and 9 and $18 \mathrm{mg} \mathrm{kg}^{-1}$ wet weight, 426 respectively (Hamre et al. 2013; Hamre et al. 2008). Theoretically, one should supplement more Asc than 427 vitamin E, although the exact optimal ratio has not yet been identified. Seventeen commercial salmon 428 feeds analyzed in a fish feed surveillance program performed at NIFES in 2015, contained between 118 429 and $418 \mathrm{mg} \mathrm{kg}^{-1} \mathrm{Asc}$, one feed contained 800 and two feeds contained more than $1300 \mathrm{mg} \mathrm{kg}^{-1}$ Asc. The 430 concentration of Asc in the feeds was frequently below the concentration of $\alpha$-TOH (NIFES unpublished 431 results).

432 Whole body Se concentration followed a first order relationship with the dietary concentration both in 433 parr and post-smolt, and the retention was not affected by NP supplementation. A similar relationship 434 was found in zebrafish, but this species had higher whole body Se concentration at similar 435 supplementation levels. The difference may be species dependent or perhaps due to the use of Se 436 enriched yeast containing mainly selenomethionine as the Se source in the zebrafish (Penglase et al. 2014) 437 and selenite $\left(\mathrm{Na}_{2} \mathrm{SeO}_{3}\right)$ here (Lorentzen et al. 1994). The basal diet contained 0.4-0.5 mg kg-1 Se, while the 438 requirement in rainbow trout is estimated at $0.15-0.38 \mathrm{mg} \mathrm{kg}^{-1}$ (Hilton et al. 1980). It is therefore unlikely 439 that fish fed the diets used in this study would become Se deficient. Judged by retention efficiency, the Se 440 present in the feed ingredients had similar bioavailability to the added selenite. If gpx1 expression had 441 been affected by low Se in this study, increased NP would probably have increased this response (Hilton 442 et al. 1980; Penglase et al. 2014). However, gpx1 was not expressed according to this hypothesis in either 443 trial. Retention and body concentrations of Se were higher in seawater than in fresh water, possibly 444 caused by differences in waterborne Se concentrations. Se toxicity was probably not encountered in the 445 present study, since the diet with the highest NP inclusion contained 1.1 and $1.4 \mathrm{mg} \mathrm{kg}^{-1} \mathrm{Se}$, which is below 446 levels reported to be toxic in fish (Penglase et al. 2014).

447 To examine whether the graded dietary NP affected redox regulation in the salmon, we measured 448 GSH/GSSG concentrations in liver and muscle and calculated the resulting $\mathrm{E}_{\mathrm{GSH}}$. In Trial 1, there was a 
449 tendency $(p=0.06-0.07)$ that NP supplementation below $150 \%$ gave more reduced fish, resulting from 450 higher concentrations of GSH. Considering the above discussion, it is unlikely that this effect would have 451 been caused by low levels of vitamin C, E or Se. The diets also had graded levels of taurine and methionine 452 (Hemre et al. 2016) and at low levels of these nutrients, GSH synthesis or recycling and a resulting lowered $453 \mathrm{E}_{\mathrm{GSH}}$ could have been stimulated to protect against oxidation induced by low taurine (Jong et al. 2012; 454 Penglase et al. 2015), consistant with the relatively higher liver gclc, g6pd and gr expressions at low NP 455 inclusion. In Trial 2, there were no effects of diet on GSH/GSSG concentrations and no correlation between 456 diet and expression of the genes coding for GSH metabolizing enzymes. The higher muscle TBARS at low 457 NP inclusion in both trials confirm that fish fed low levels of micronutrients and selected amino acids may 458 have become oxidized. Overall, the results confirm that the tissue GSH/GSSG concentrations are relatively 459 stable within experiments with salmon, even with large variations in dietary composition, as found by 460 Hamre et al. (2010b).

461 However, the GSH/GSSG concentrations and $E_{G S H}$ were different in Trial 1 and 2, the fish in Trial 2 being 462 more oxidized, with less GSH both in liver and muscle and more GSSG in the liver, than the fish in Trial 1. 463 Expression of liver gpx1 (cytosol and mitochondria) and gpx3 (extracellular) was also higher in Trial 2, 464 indicating excess activity in removal of $\mathrm{H}_{2} \mathrm{O}_{2}$ at the expense of $\mathrm{GSH}$. This corresponds with an increased 465 466

consumption of Asc in Trial 2. These results indicate that the fish in Trial 2 experienced some sort of oxidative stress. The fish did not seem to be diseased, since the growth and feed intake were good and mortalities were negligible (Hemre et al. 2016). The feed was not analyzed for oxidation, however, oxidized feed most often leads to reduced vitamin E retention (Baker \& Davies 1997; Hung et al. 1981), which was not encountered in the present study. The samples in Trial 2 were taken in June, with rapidly increasing water temperatures and longer day light, resulting in strong growth stimulation in salmon. In cod larvae fed copepods, a similar growth stimulation correlated with more oxidized fish having a higher whole body $\mathrm{E}_{\mathrm{GSH}}$ (Karlsen et al. 2015; Penglase et al. 2015). Based on these observations, we hypothesize that redox regulation is involved in surges in growth.

\section{Conclusion}

This study gives no indications that diets rich in plant ingredients increase the vitamin C, E or Se requirements in Atlantic salmon. Feeds produced using the current feed ingredients, seem to have sufficient amounts of $\alpha-\mathrm{TOH}$ and Se from the feed ingredients alone. However, due to possible variations 
479 in ingredient quality, feed processing and farming conditions, feeds should be supplemented with above $480150 \mathrm{mg} \mathrm{kg}^{-1} \alpha-\mathrm{TOH}$ equivalents. The Se in plant based feed ingredients may vary and Se supplementation 481 may be warranted in some cases. However, the legal upper limit of Se in fish feeds in the European Union 482 is $0.5 \mathrm{mg} \mathrm{kg}^{-1}$ (Regulation (EC) No 1831/2003) and the law comes into force if the feeds are supplemented. 483 Fish fed the highest concentration of Se $\left(1.4 \mathrm{mg} \mathrm{kg}^{-1}\right)$ did not show any signs of toxicity. Based on body 484 concentrations, Asc supplementation should be above $190 \mathrm{mg} \mathrm{kg}{ }^{-1}$, where the whole body Asc 485 concentration leveled off in Trial 1. At this supplementation level, Asc deficiency can be avoided in periods 486 with oxidative stress and optimal immune function and stress resistance can be obtained. Redox 487 regulation, which includes differential consumption of antioxidant nutrients, seems to change during the 488 production cycle of Atlantic salmon.

\section{Acknowledgement}

490 We want to thank the technical staff at NIFES, IMR and GIFAS for great work with the practical aspects of 491 this study.

492 
493 Table 1. Feed formulation Trial 1, and with slight difference given for Trial 2 in parenthesis (Trial 2).

494 Nutrient premix, methionine, taurine and cholesterol were added to the diets in graded amounts, and 495 balanced by reducing the content of field peas in the diets, all other ingredients were used in equal 496 amounts in all diets. Numbers are in $\mathrm{g} \mathrm{kg}^{-1}$.

\begin{tabular}{|c|c|c|c|c|c|c|c|}
\hline Composition & ONP & 25NP & 50NP & 100NP & 150NP & 200NP & 400NP \\
\hline $\begin{array}{l}\text { Fish meal SA } 68 \\
\text { superprime }\end{array}$ & 80 & 80 & 80 & 80 & 80 & 80 & 80 \\
\hline Krill meal & 24.2 & 24.2 & 24.2 & 24.2 & 24.2 & 24.2 & 24.2 \\
\hline Soy Prot. Conc. $60 \%$ & 180 & 180 & 180 & 180 & 180 & 180 & 180 \\
\hline Corn gluten 60 & 40 & 40 & 40 & 40 & 40 & 40 & 40 \\
\hline Pea protein 75 & $124(130)$ & $124(130)$ & $124(130)$ & $124(130)$ & $124(130)$ & $124(130)$ & $124(130)$ \\
\hline Wheat gluten & $180(150)$ & $180(150)$ & $180(150)$ & $180(150)$ & $180(150)$ & $180(150)$ & $180(150)$ \\
\hline Wheat & $61(60)$ & $61(60)$ & $61(60)$ & $61(60)$ & $61(60)$ & $61(60)$ & $61(60)$ \\
\hline Field peas & 100 & 98 & 95 & 90 & 85 & 80 & 60 \\
\hline Fish oil, capelin & $35(44)$ & $35(44)$ & $35(44)$ & $35(44)$ & $35(44)$ & $35(44)$ & $35(44)$ \\
\hline Rapeseed oil & $79(88)$ & $79(88)$ & $79(88)$ & $79(88)$ & $79(88)$ & $79(88)$ & $79(88)$ \\
\hline Linseed oil & 22 & 22 & 22 & 22 & 22 & 22 & 22 \\
\hline Palm kernel oil & $44(48)$ & $44(48)$ & $44(48)$ & $44(48)$ & $44(48)$ & $44(48)$ & $44(48)$ \\
\hline Nutrient premix * & 0 & 0.25 & 0.5 & 1.0 & 1.5 & 2.0 & 4.0 \\
\hline Histidine & 0.00 & 0.34 & 0.68 & 1.36 & 2.04 & 2.72 & 5.44 \\
\hline Cholesterol & 0.00 & 0.28 & 0.56 & 1.13 & 1.69 & 2.25 & 4.50 \\
\hline
\end{tabular}
*Times requirement. All diets were added $38 \mathrm{~g} \mathrm{~kg}^{-1}$ monosodium phosphate, mineral additions were adjusted to each micronutrient premix (Lock et al. in preparation). All diets were added $9.3 \mathrm{~g} \mathrm{~kg}^{-1}$ lysine, $1.8 \mathrm{~g} \mathrm{~kg}^{-1}$ threonine, $8 \mathrm{~g} \mathrm{~kg}^{-1}$ choline (50\%), $0.25 \mathrm{~g} \mathrm{~kg}^{-1}$ barox becp dry, $0.5 \mathrm{~g} \mathrm{~kg}^{-1}$ yttrium oxide. 
502 Table 2. Analyzed feed composition. All results are the mean of two analytical parallels. Protein, lipid, 503 starch ash and dry matter are given in $\mathrm{g} \mathrm{kg}^{-1}$ dry weight, energy as $\mathrm{MJ} \mathrm{kg}^{-1}$, while all other diet components 504 are given as $\mathrm{mg} \mathrm{kg}^{-1}$. Slight difference in macronutrient composition; Trial 2 is given in parenthesis. For 505 the micronutrients close to similar levels existed in both experiments.

\begin{tabular}{|c|c|c|c|c|c|c|c|}
\hline & ONP & 25NP & 50NP & 100NP & 150NP & 200NP & 400NP \\
\hline \multicolumn{8}{|l|}{ Proximate } \\
\hline \multicolumn{8}{|l|}{$\begin{array}{l}\text { composition, } \\
g k^{-1} d w\end{array}$} \\
\hline Protein & $453(480)$ & 469 (472) & 449 (440) & 456 (480) & $462(480)$ & 470 (480) & 461 (480) \\
\hline Lipid & $213(220)$ & 203 (220) & 219 (210) & $211(230)$ & $208(220)$ & 197 (240) & 195 (220) \\
\hline Starch & 112 & 112 & 109 & 104 & 106 & 107 & 94 \\
\hline Ash & 66 & 68 & 66 & 67 & 69 & 60 & 75 \\
\hline Dry matter & 910 (950) & $930(940)$ & $920(930)$ & $920(930)$ & 930 & 920 (930) & 920 \\
\hline $\begin{array}{l}\text { Energy, } \quad \text { MJ } \\
\text { kg-1 }^{-1}\end{array}$ & 22.8() & 22.7 & 22.6 & 22.7 & 22.4 & 22.5 & 22.0 \\
\hline \multicolumn{8}{|c|}{$\begin{array}{l}\text { Micronutrients involved in } \\
\text { redox regulation } \mathrm{mg} \mathrm{kg}^{-1} \\
\mathrm{dw}\end{array}$} \\
\hline \multicolumn{8}{|l|}{ Trial1: } \\
\hline$\alpha-\mathrm{TOH}$ & 48 & 72 & 84 & 118 & 153 & 193 & 339 \\
\hline $\mathrm{Y}-\mathrm{TOH}$ & 49 & 54 & 60 & 61 & 51 & 52 & 51 \\
\hline Ascorbic acid & $4.7^{1}$ & 21 & 43 & 86 & 143 & 192 & 351 \\
\hline Selenium & 0.42 & 0.45 & 0.52 & 0.62 & 0.80 & 1.04 & 1.39 \\
\hline \multicolumn{8}{|l|}{ Trial2: } \\
\hline$\alpha-\mathrm{TOH}$ & 76 & 91 & 109 & 141 & 178 & 230 & 239 \\
\hline $\mathrm{v}-\mathrm{TOH}$ & 54 & 51 & 51 & 52 & 54 & 61 & 55 \\
\hline Ascorbic acid & $<5.5$ & 14 & 28 & 63 & 89 & 140 & 170 \\
\hline Selenium & 0.47 & 0.48 & 0.56 & 0.79 & 0.91 & 1.0 & 1.1 \\
\hline
\end{tabular}

$506{ }^{1}$ Below the limit of quantification, uncertain value.

507 


\begin{tabular}{|c|c|c|c|c|c|c|}
\hline Gene & Full gene name & Accession no. & Forward primer & Reverse primer & $\begin{array}{l}\text { Amplicon } \\
\text { size (bp) }\end{array}$ & $\begin{array}{l}\text { PCR efficiency } \\
a / b^{*}\end{array}$ \\
\hline cuznsod & CuZn superoxide dismutase & BG936553 & CCACGTCCATGCCTTTGG & TCAGCTGCTGCAGTCACGTT & 141 & $1.94 / 1.95$ \\
\hline mnsod & $\mathrm{Mn}$ superoxide dismutase & DY718412 & GTTTCTCTCCAGCCTGCTCTAAG & CCGCTCTCCTTGTCGAAGC & 227 & $1.96 / 2.06$ \\
\hline cat & Catalase & BG935638 & CCCAAGTCTTCATCCAGAAACG & CGTGGGCTCAGTGTTGTTGA & 101 & $1.90 / 1.97$ \\
\hline$g p \times 3$ & Glutathione peroxidase 3 & DW561212 & TTCCCCTCCAATCAGTTTGG & ATCCCCCCTCTGGAATAGCA & 123 & $1.97 / 2.05$ \\
\hline$g r$ & Glutathione reductase & $\begin{array}{l}\text { BG934480 } \\
>\text { Contig7869_Atlan }\end{array}$ & CCAGTGATGGCTTTTTTGAACTT & CCGGCCCCCACTATGAC & 61 & 2.03/1.97 \\
\hline g6pd & Glucose-6-Phosphate Dehydrogenase & tic_salmon & CTTTGGGCCAATCTGGAACA & TCCCGGATGATTCCAAAGTC & 114 & $2.08 / 2.00$ \\
\hline nfe2l2 & Nuclear factor (erythroid-derived 2)-like 2 & $\begin{array}{l}\text { BT044699 } \\
>\text { Contig16361_Atla }\end{array}$ & TCGCTGAAGGAGGAGAAGGA & GTCCCTCAGCAGACGGAAAA & 120 & $1.83 / 2.05$ \\
\hline
\end{tabular}

${ }^{*} \mathrm{a}=$ Trial 1, b=Trial 2 


\section{Trial 1}
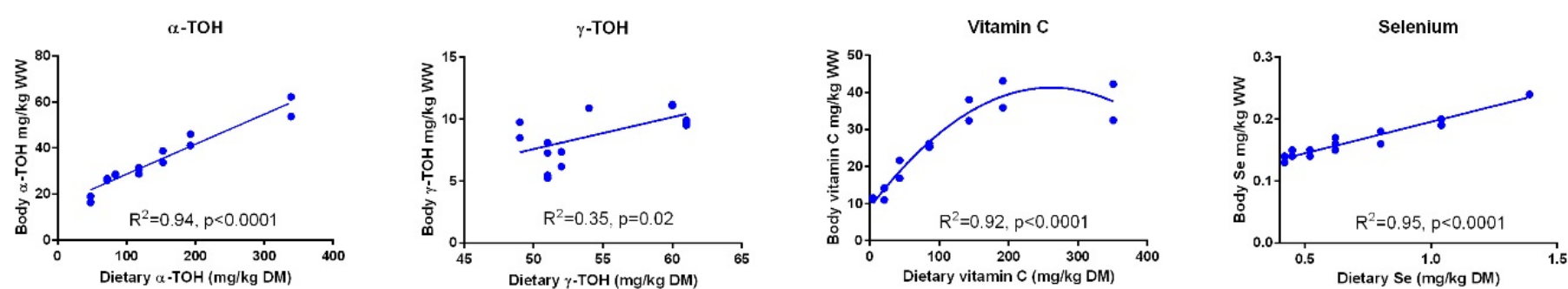

\section{Trial 2}
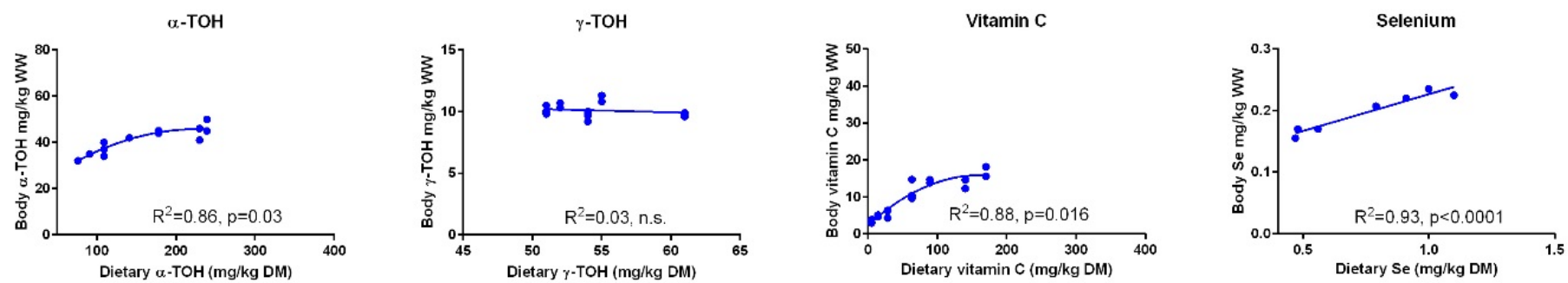

Figure 1. Whole body concentrations ( $\mathrm{mg} \mathrm{kg}^{-1}$ wet weight) of redox dependent micronutrients in Atlantic salmon parr (Trial 1 ) and post-smolt (Trial 2 ) in response to dietary supplementation of micronutrients and selected amino acids at supplementation of $0-400 \%$ NP. Data were first fitted to second order polynomials and the fit was then compared to a first order polynomial fit, which was chosen when p $>0.05$ for the second order equation. The $p$ given in figures with first order and second order fits indicate that the slope is significantly different from 0 or that second order fits are significantly better than first order fits, respectively. n.s., not significant 


\section{Trial 1}
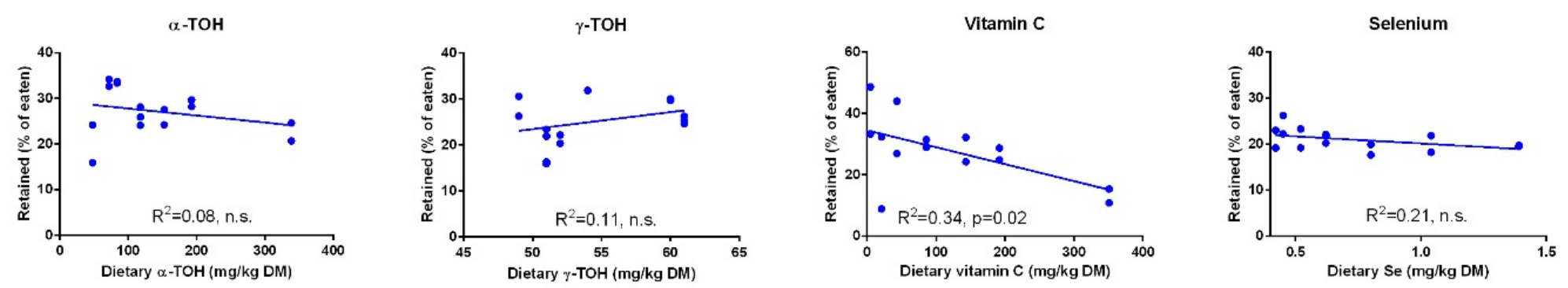

\section{Trial 2}
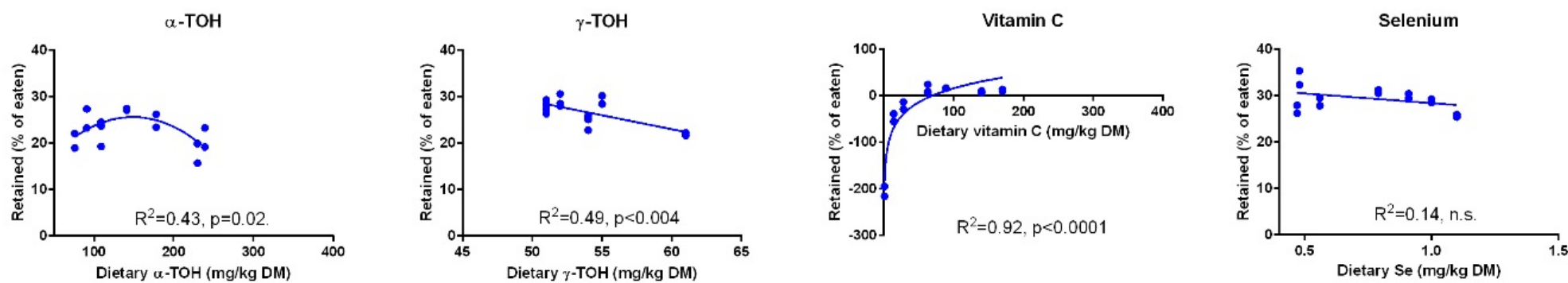

Figure 2. Retention (\% of eaten) of redox dependent micronutrients in Atlantic salmon parr (Trial 1 ) and smolt (Trial 2) in response to dietary supplementation of micronutrients and selected amino acids at 0-400\% NP. Data were first fitted to second order polynomials and the fit was then compared to a first order polynomial equation fit. $\alpha$-Tocopherol in Trial 2 had significantly best fit to the second order equation $(p<0.05)$. Vitamin $\mathrm{C}$ retention fitted a logarithmic equation better than a second order polynomial $(p<0.001)$. The $p$ given in figures with first order fits indicates that the slope is significantly different from 0 . (n.s.; not significant) 


\section{Trial 1}

GSH

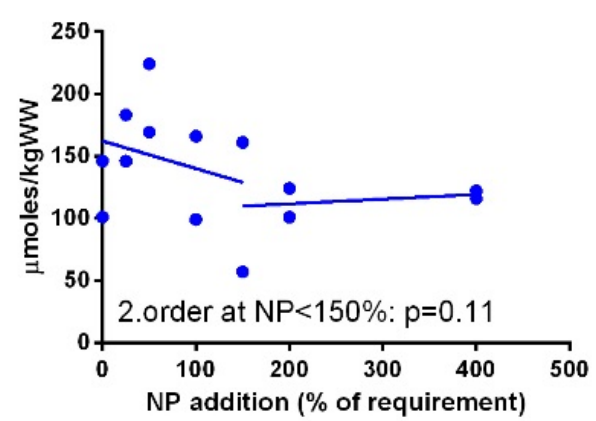

GSSG

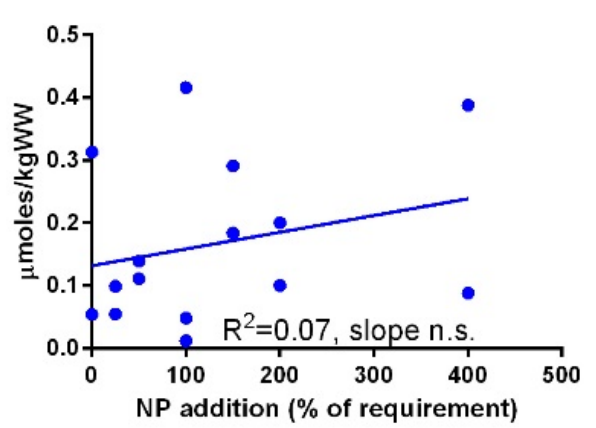

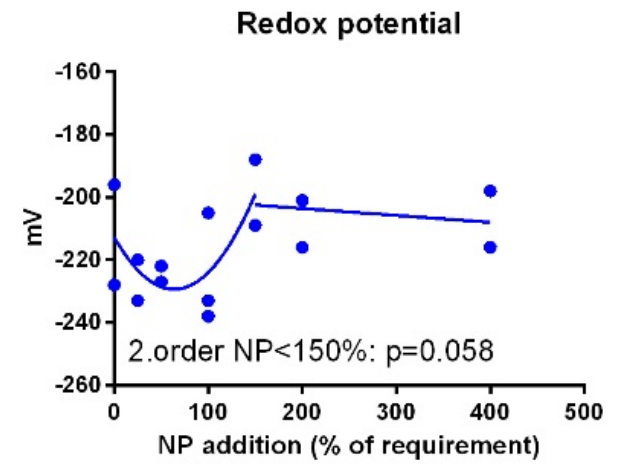

\section{Trial 2}

GSH

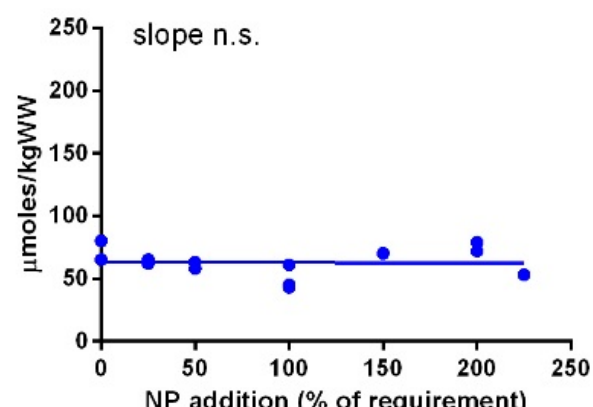

GSSG

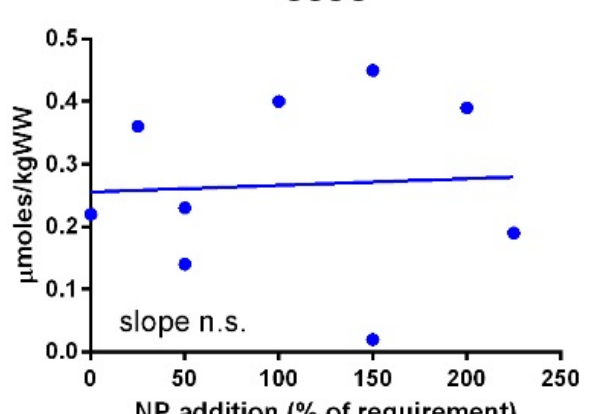

Redox potential

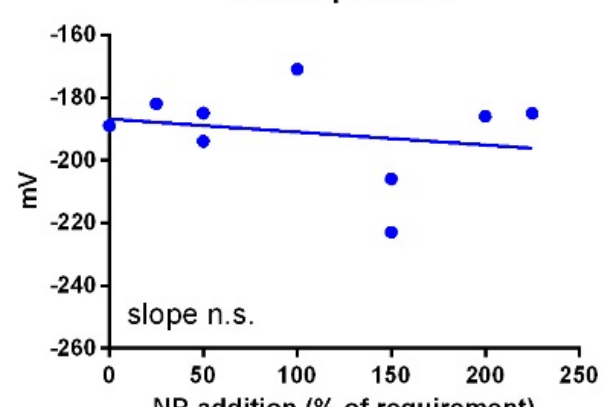

NP addition (\% of requirement)

Figure 3. Muscle reduced and oxidized glutathione (GSH and GSSG, $\mu$ moles/kg wet weight) and the GSH based redox potential (mV) in Atlantic

salmon parr (Trial 1) and post-smolt (Trial 2) in response to dietary supplementation of micronutrients and selected amino acids at 0-400\% NP. 


\section{Trial 1}
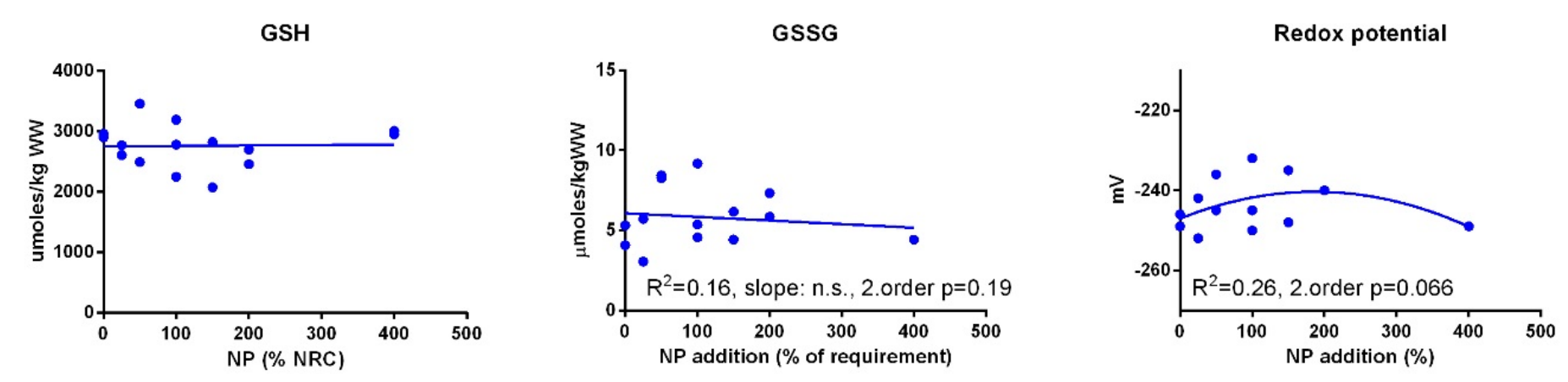

\section{Trial 2}
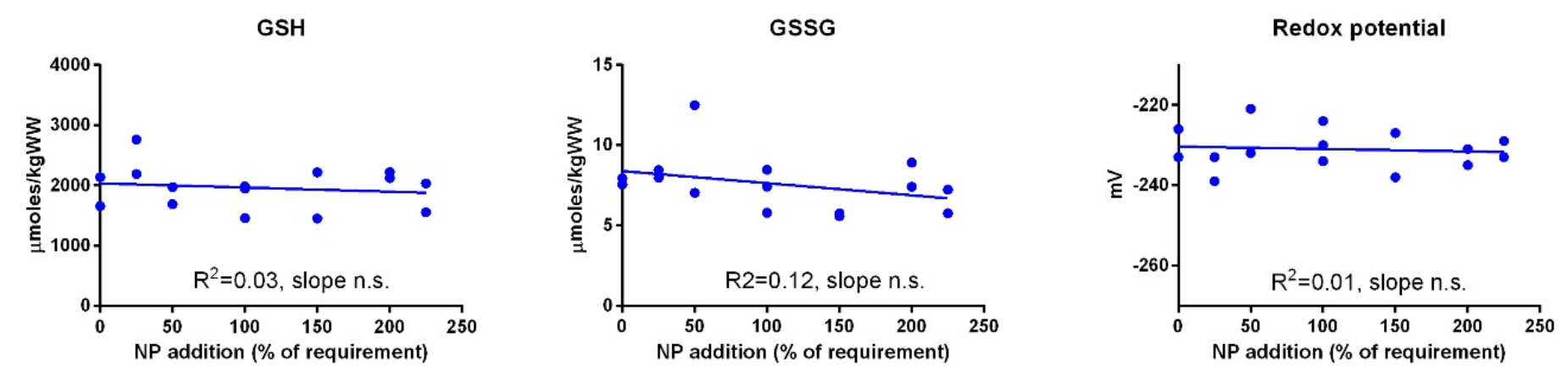

Figure 4. Liver reduced and oxidized glutathione (GSH and GSSG, $\mu$ moles $\mathrm{kg}^{-1}$ wet weight) and the GSH based redox potential (mV) in Atlantic salmon parr (Trial 1) and post-smolt (Trial 2) in response to dietary supplementation of micronutrients and selected amino acids at 0-400\% NP. 
Trial 1

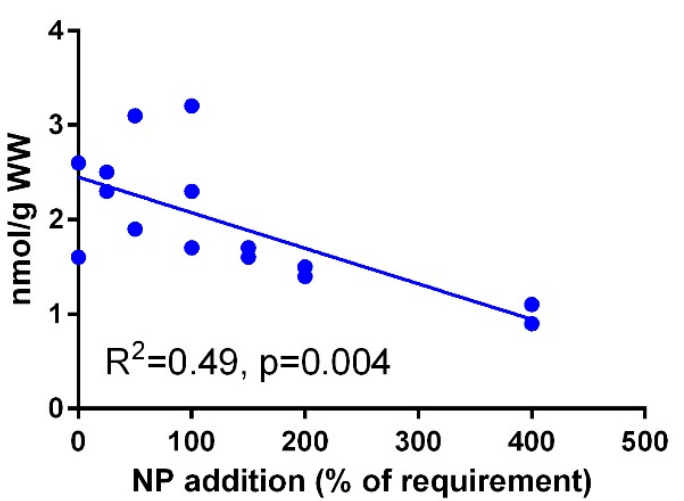

Trial 2

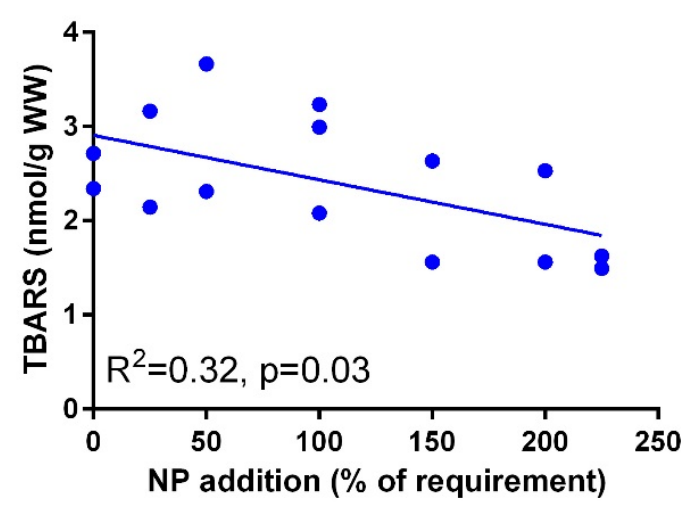

533

536

537

Figure 5. Muscle TBARS (nmoles $\mathrm{g}^{-1} \mathrm{ww}$ ) in Atlantic salmon parr (Trial 1) and post-smolt (Trial 2) in response to dietary supplementation of micronutrients and selected amino acids at $0-400 \%$ NP. 

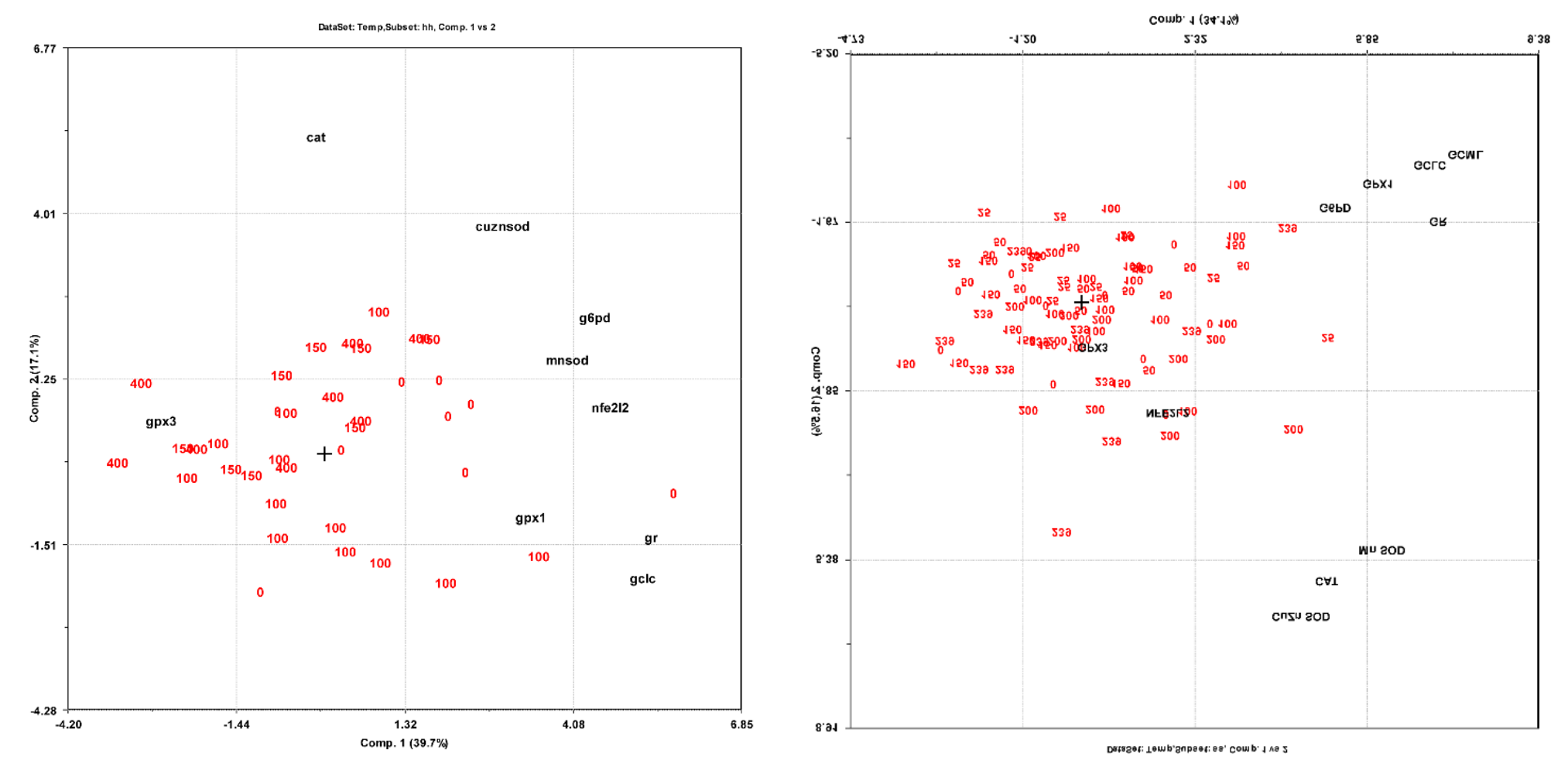

540 Figure 6. PCA bi-plots on expression of redox dependent genes related to dietary supplementation of micronutrients and selected amino acids at $5410-400 \%$ NP. 
542

543

544

545

546

547

548

549

550

551

552

553

554

555

556

557

558

559

560

561

562

563

564

565

566

567

568

569

570

571

572

573

574

575

576

577

578

579

580

581

582

583

584

585

586

587

588

\section{References}

Alfthan G, Eurola M, Ekholm P, Venalainen ER, Root T, Korkalainen K, Hartikainen H, Salminen P, Hietaniemi V, Aspila P et al. . 2015. Effects of nationwide addition of selenium to fertilizers on foods, and animal and human health in Finland: From deficiency to optimal selenium status of the population. Journal of Trace Elements in Medicine and Biology 31:142-147.

Baker RTM, and Davies SJ. 1997. Modulation of tissue alpha-tocopherol in African catfish, Clarias gariepinus (Burchell), fed oxidized oils, and the compensatory effect of supplemental dietary vitamin E. Aquaculture Nutrition 3:91-97.

Barnes MJ, and Kodicek E. 1972. Biological hydroxylations and ascorbic acid with special regard to collagen metabolism. Vitam Horm 30:1-43.

Brigelius-Flohe R. 1999. Tissue-specific functions of individual glutathione peroxidases. Free Radical Biology and Medicine 27:951-965.

Buettner GR. 1993. The Pecking Order of Free-Radicals and Antioxidants - Lipid-Peroxidation, AlphaTocopherol, and Ascorbate. Archives of Biochemistry and Biophysics 300:535-543.

CEN. 1999. Foodstuffs - Determination of vitamin E by high performance liquid chromatography Measurement of alpha-, beta-, gamma- and delta-tocopherols. Comitè Europeèn de Normalisation prEN 12822.

Dabrowski K, Lee KJ, Guz L, Verlhac V, and Gabaudan J. 2004. Effects of dietary ascorbic acid on oxygen stress (hypoxia or hyperoxia), growth and tissue vitamin concentrations in juvenile rainbow trout (Oncorhynchus mykiss). Aquaculture 233:383-392.

Espe M, Lemme A, Petri A, and El-Mowafi A. 2006. Can Atlantic salmon (Salmo salar) grow on diets devoid of fish meal? Aquaculture 255:255-262.

Espe M, Lemme A, Petri A, and El-Mowafi A. 2007. Assessment of lysine requirement for maximal protein accretion in Atlantic salmon using plant protein diets. Aquaculture 263:168-178.

Gabaudan J, and Verlhac V. 2001. Critical review of the requirements of ascorbic acid in cold and cool water fishes (salmonids, percids, plecoglossids and flatfishes). In: Dabrowski K, ed. Ascorbic acid in aquatic organisms Status and perspectives. London, New York, Washington D.C:: CRC press, 33-48.

Go Y, and Jones DJ. 2013. The Redox Proteome. Journal of Biological Chemistry.

Golli F, and Azzi A. 2010. Present trends in vitamin E research. Biofactors 36:33-42.

Gould BS, Manner G, Goldman HM, and Stolman JM. 1960. Some Aspects of Collagen Formation. Annals of the New York Academy of Sciences 85:385-398.

Hamre K. 1995. Metabolism, interactions and requirement of vitamin E in Atlantic salmon (Salmo salar, L.) Dr. scient thesis University of Bergen.

Hamre K. 2011. Metabolism, interactions, requirements and functions of vitamin $\mathrm{E}$ in fish. Aquaculture Nutrition 17:98-115.

Hamre K, Berge RK, and Lie $\varnothing$. 1998. Turnover of $\alpha_{-}^{-}, \gamma_{-}^{-}$, and $\delta$-tocopherol and distribution in subcellular and lipoprotein fractions indicate presence of an hepatic tocopherol binding protein in Atlantic salmon (Salmo salar, L.). Fish Physiol Biochem 18:71-83.

Hamre K, Berge RK, Waagb $\varnothing \mathrm{R}$, and Lie $\varnothing$. 1997. Vitamins $C$ and $E$ interact in juvenile Atlantic salmon (Salmo salar, L.). Free Rad Biol Med 22:137-149.

Hamre K, Kolås K, and Sandnes K. 2010a. Protection of fish feed, made directly from marine raw materials, with natural antioxidants. Food Chemistry 119:270-278.

Hamre K, and Lie $\varnothing$. 1995. Minimum requirement of vitamin E for Atlantic salmon, Salmo salar, L., at first feeding. Aquaculture Res 26:175-184.

Hamre K, and Lie $\varnothing$. 1997. Retained levels of dietary $\alpha$-, $\gamma$ - and $\delta$-tocopherol in tissues and body fluids of Atlantic salmon (Salmo salar, L.). Aquaculture Nutr 3:99-107. 
589

590

591

592

593

594

595

596

597

598

599

600

601

602

603

604

605

606

607

608

609

610

611

612

613

614

615

616

617

618

619

620

621

622

623

624

625

626

627

628

629

630

631

632

633

634

Hamre K, Nordgreen A, Grøtan E, and Breck O. 2013. A holistic approach to development of diets for Ballan wrasse (Labrus berggylta) - a new species in aquaculture. PeerJ 1:e99: 10.7717/peerj.7799.

Hamre K, Næss T, Espe M, Holm JC, and Lie $\varnothing$. 2001. A formulated diet for Atlantic halibut (Hippoglossus hippoglossus, L.) larvae. Aqua Nutr 7:123-132.

Hamre K, Penglase SJ, Rasinger JD, Skjaerven KH, and Olsvik PA. 2014. Ontogeny of redox regulation in Atlantic cod (Gadus morhua) larvae. Free Radical Biology and Medicine 73:337-348.

Hamre K, Srivastava A, Rønnestad I, Mangor-Jensen A, and Stoss J. 2008. Several micronutrients in the rotifer Brachionus sp may not fulfil the nutritional requirements of marine fish larvae. Aquaculture Nutr 14:51-60.

Hamre K, Torstensen BE, Maage A, Waagb $\varnothing$ R, Berge RK, and Albrektsen S. 2010b. Effects of dietary lipid, vitamins and minerals on total amounts and redox status of glutathione and ubiquinone in tissues of Atlantic salmon (Salmo salar): a multivariate approach. Br J Nutr 104:980-988.

Hemre G, Lock E, Olsvik PA, Hamre K, Espe M, Torstensen BE, Silva J, Hansen A, Waagb $\varnothing$ R, Johansen JS et al. . 2016. Atlantic salmon (Salmo salar) require increased dietary levels of B-vitamins when fed diets with high inclusion of plant based ingredients. PeerJ 4:e2493, https://doiorg/107717/peerj2493.

Higuchi R, Fockler C, Dollinger G, and Watson R. 1993. Kinetic PCR analysis: real-time monitoring of DNA amplification reactions. Nat Biotech 11:1026-1030.

Hilton JW, Hodson PV, and Slinger SJ. 1980. The requirement and toxicity of selenium in rainbow trout (Salmo Gairdneri). J Nutr 110:2527-2535.

Hung SSO, Cho CY, and Slinger SJ. 1981. Effect of Oxidized Fish Oil, Dl-Alpha-Tocopheryl Acetate and Ethoxyquin Supplementation on the Vitamin-E Nutrition of Rainbow-Trout (Salmo-Gairdneri) Fed Practical Diets. J Nutr 111:648-657.

Huseby NE, Sundkvist E, and Svineng G. 2009. Glutathione and sulfur containing amino acids: antioxidant and conjugation activities. In: Masella R, and Mazza G, eds. Glutathione and Sulfur Containing Amino Acids in Human Health and Disease. Hoboken, NJ: Wiley.

Jones DP, and Sies H. 2015. The Redox Code. Antioxid Redox Signal 23:734-746.

Jong CJ, Azuma J, and Schaffer S. 2012. Mechanism underlying the antioxidant activity of taurine: prevention of mitochondrial oxidant production. Amino Acids 42:2223-2232.

Julshamn K, Brenna J, Holland R, and Tanner S. 1999. Plasma source mass spectrometry- New developments and applications. $R$ Soc Chem 241:167-172.

Karlsen $\varnothing$, van der Meeren T, Rønnestad I, Mangor-Jensen A, Galloway T, Kjørsvik E, and Hamre K. 2015. Copepods enhance nutritional status, growth, and development in Atlantic cod (Gadus morhua L.) larvae - can we identify the underlying factors? PeerJ 3:e902 https://dx.doi.org/10.7717/peerj.902.

Kayden HJ, and Traber MG. 1993. Absorption, lipoprotein transport, and regulation of plasma concentrations of vitamin $\mathrm{E}$ in humans. J Lipid Res 34:343-358.

Kemp M, Go YM, and Jones DP. 2008. Nonequilibrium thermodynamics of thiol/disulfide redox systems: a perspective on redox systems biology. Free Radic Biol Med 44:921-937.

Kirlin WG, Cai J, Thompson SA, Diaz D, Kavanagh TJ, and Jones DP. 1999. Glutathione redox potential in response to differentiation and enzyme inducers. Free Rad Biol Med 27:1208-1218.

Krogdahl $\AA$, Hemre G-I, and Mommsen TP. 2005. Carbohydrates in fish nutrition: digestion and absorption in postlarval stages. Aquaculture Nutrition 11:103-122.

Lorentzen M, Maage A, and Julshamn K. 1994. Effects of Dietary Selenite or Selenomethionine on Tissue Selenium Levels of Atlantic Salmon (Salmo-Salar). Aquaculture 121:359-367. 
635

636

637

638

639

640

641

642

643

644

645

646

647

648

649

650

651

652

653

654

655

656

657

658

659

660

661

662

663

664

665

666

667

668

669

670

671

672

673

674

675

676

677

678

679

680

681

682

Lygren B, Hamre K, and Waagb $\varnothing$ R. 2000. Effect of induced hyperoxia on the antioxidant status of Atlantic salmon, Salmo salar, L. fed three different levels of dietary vitamin E. Aquaculture Research 31:401-407.

Lygren B, Hjeltnes B, and Waagb $\varnothing$ R. 2001. Immune response and disease resistance in Atlantic salmon (Salmo salar, L.) fed three levels of dietary vitamin $E$ and the effect of vaccination on the liver status of antioxidant vitamins. Aquaculture International 9:401-411.

Ma Q. 2013. Role of Nrf2 in Oxidative Stress and Toxicity. Pharm Toxicol 53:401-.

Martinez-Alvarez RM, Morales AE, and Sanz A. 2005. Antioxidant defenses in fish: Biotic and abiotic factors. Reviews in Fish Biology and Fisheries 15:75-88.

Meister A. 1994. Glutathione Ascorbic Acid Antioxidant System in Animals. J Biol Chem 269:9397-9400.

Meland SJ. 1995. Biologisk aktivitet av ulike vitamin E forbindelser hos yngel av atlantisk laks (Salmo salar, L) Cand. scient. thesis. University of Bergen, Norway.

Morgan B, Ezerina D, Amoako TNE, Riemer J, Seedorf M, and Dick TP. 2013. Multiple glutathione disulfide removal pathways mediate cytosolic redox homeostasis. Nature Chem Biol 9:119-125.

Mrtensson J, and Meister A. 1991. Glutation deficiency decreases tissue ascorbate levels in newborn rats: Ascorbate spares glutathion and protects. Proc Nat Acad Sci USA 88:4656-4660.

Mæland A, and Waagb $\varnothing$ R. 1998. Examination of the qualitative ability of some cold water marine teleosts to synthesise ascorbic acid. Comparative Biochemistry and Physiology Part A 121:249255.

NIFES. unpublished results. Latest data from the Norwegian National Feed Surveillance Program. Will be published on www.nifes.no.

NRC. 2011. Nutrient requirements of fish and shrimp: The Natioanal Academic Press, Washington D.C.

Olsvik PA, Torstensen BE, Hemre GI, Sanden M, and Waagbø R. 2011. Hepatic oxidative stress in Atlantic salmon (Salmo salar L.) transferred from a diet based on marine feed ingredients to a diet based on plant ingredients. Aquaculture Nutrition 17:E424-E436.

Penglase S, Hamre K, Rasinger JD, and Ellingsen S. 2014. Selenium status affects selenoprotein expression, reproduction, and F-1 generation locomotor activity in zebrafish (Danio rerio). British Journal of Nutrition 111:1918-1931.

Penglase S, Nordgreen A, van der Meeren T, Olsvik PA, Sæle O, Sweetman JW, Bæverfjord G, Helland S, and Hamre K. 2010. Increasing the level of selenium in rotifers (Brachionus plicatilis 'Cayman') enhances the mRNA expression and activity of glutathione peroxidase in cod (Gadus morhua L.) larvae. Aquaculture 306:259-269.

Penglase SJ, Edvardsen RB, Furmanek T, Rønnestad I, Karlsen $\varnothing$, Van der Meeren T, and Hamre K. 2015. Diet affects the redox system in developing Atlantic cod (Gadus morhua) larvae Redox Biology 5:308-318.

Rigotti A. 2007. Absorption, transport, and tissue delivery of vitamin E. Molecular Aspects of Medicine 28:423-436.

Sandnes K, Torrissen O, and Waagbø R. 1992. The minimum dietary requirement of vitamin C in Atlantic salmon (Salmo salar) fry using Ca-ascorbate-2-monophosphate as dietary source. Fish Physiol Biochem 10:315-319.

Schafer FQ, and Buettner GR. 2001. Redox environment of the cell as viewed through the redox state of the glutathione disulfide/glutathione couple. Free Radical Biology and Medicine 30:1191-1212.

Skjærven KH, Penglase S, Olsvik PA, and Hamre K. 2013. Redox regulation in Atlantic cod (Gadus morhua) embryos developing under normal and heat-stressed conditions. Free Radical Biology and Medicine 57:29-38.

Sunde RA, Raines AM, Barnes KM, and Evenson JK. 2009. Selenium status highly regulates selenoprotein mRNA levels for only a subset of the selenoproteins in the selenoproteome. Bioscience Reports 29:329-338. 
683

684

685

686

687

688

689

690

691

692

693

694

695

696

697

698

699

700

701

702

703

704

705

706

707

708

709

710

711

712
Tappel AL. 1962. Vitamin E as the biological lipid antioxidant. Vitamins and Hormones 20:493-510.

Terova G, Saroglia M, Papp ZG, and Cecchini S. 1998. Dynamics of collagen indicating amino acids, in embryos and larvae of sea bass (Dicentrarchus labrax) and gilthead sea bream (Sparus aurata), originated from broodstocks fed with different vitamin C content in the diet. Comparative Biochemistry and Physiology a-Molecular and Integrative Physiology 121:111-118.

Timme-Laragy A, Goldstone J, Imhoff B, Stegeman J, Hahn M, and Hansen J. 2013. Glutathione redox dynamics and expression of glutathione-related genes in the developing embryo. Free radical biology \& medicine 65:89-101.

Trichet VV. 2010. Nutrition and immunity: an update. Aquaculture Research 41:356-372.

Waagb $\varnothing$ R. 1994. The impact of nutritional factors on the immune system in Atlantic salmon, Salmo salar, L.: A review. Aquaculture and Fisheries Management 25:175-197.

Waagb $\varnothing$ R. 2006. Feeding and disease resistence in fish. In: Mosenthin R, Zentek J, and Zebrowska T, eds. Biology of growing animals. London: Elsevier Ltd, 387-415.

Waagb $\varnothing$ R, and Sandnes K. 1996. Effects of dietary vitamin C on growth and parr-smolt transformation in Atlantic salmon, Salmo salar, L. Aquaculture Nutrition 2:65-69.

Wallert M, Schmolz L, Galli F, Birringer M, and Lorkowski S. 2014. Regulatory metabolites of vitamin E and their putative relevance for atherogenesis. Redox Biology 2:495-503.

Weiss SL, Evenson JK, Thompson KM, and Sunde RA. 1996. The selenium requirement for glutathione peroxidase mRNA level is half of the selenium requirement for glutathione peroxidase activity in female rats. Journal of Nutrition 126:2260-2267.

Weiss SL, Evenson JK, Thompson KM, and Sunde RA. 1997. Dietary selenium regulation of glutathione peroxidase mRNA and other selenium-dependent parameters in male rats. Journal of Nutritional Biochemistry 8:85-91.

Woodward B. 1994. Dietary Vitamin Requirements of Cultured Young Fish, with Emphasis on Quantitative Estimates for Salmonids. Aquaculture 124:133-168.

Yoshida H, Yusin M, Ren I, Kuhlenkamp J, Hirano T, Stolz A, and Kaplowitz N. 1992. Identification, Purification, and Immunochemical Characterization of a Tocopherol-Binding Protein in Rat-Liver Cytosol. Journal of Lipid Research 33:343-350. 